Geological Society, London, Special Publications

\title{
Strain partitioning of active transpression within the Lebanese restraining bend of the Dead Sea Fault (Lebanon and SW Syria)
}

F. Gomez, T. Nemer, C. Tabet, M. Khawlie, M. Meghraoui and M. Barazangi

Geological Society, London, Special Publications 2007; v. 290; p. 285-303 doi:10.1144/290.10

Email alerting service

Permission request

Subscribe click here to receive free email alerts when new articles cite this article

click here to seek permission to re-use all or part of this article

click here to subscribe to Geological Society, London, Special Publications or the Lyell Collection

Notes

Downloaded by on 18 December 2007 


\title{
Strain partitioning of active transpression within the Lebanese restraining bend of the Dead Sea Fault (Lebanon and SW Syria)
}

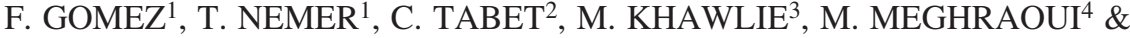 \\ M. BARAZANGI ${ }^{5}$ \\ ${ }^{1}$ Department of Geological Sciences, University of Missouri, Columbia, \\ Missouri 65211,USA (e-mail: fgomez@missouri.edu) \\ ${ }^{2}$ Lebanese National Council for Scientific Research, Beirut, Lebanon \\ ${ }^{3}$ Lebanese National Center for Remote Sensing, Beirut, Lebanon \\ ${ }^{4}$ EOST, Institut de Physique du Globe, UMR 7516, Strasburg, France \\ ${ }^{5}$ Institute for the Study of the Continents, Snee Hall, Cornell University, Ithaca, \\ New York 14853, USA
}

\begin{abstract}
Recent neotectonic, palaeoseismic and GPS results along the central Dead Sea fault system elucidate the spatial distribution of crustal deformation within a large (c.180-km-long) restraining bend along this major continental transform. Within the 'Lebanese' restraining bend, the Dead Sea fault system splays into several key branches, and we suggest herein that active deformation is partitioned between NNE-SSW strike-slip faults and WNW-ESE crustal shortening. When plate motion is resolved into strike-slip parallel to the two prominent NNESSW strike-slip faults (the Yammouneh and Serghaya faults) and orthogonal motion, their slip rates are sufficient to account for all expected strike-slip motion. Shortening of the Mount Lebanon Range is inferred from the geometry and kinematics of the Roum Fault, as well as preliminary quantification of coastal uplift. The results do not account for all expected crustal shortening, suggesting that some contraction is probably accommodated in the Anti-Lebanon Range. It also seems unlikely that the present kinematic configuration characterizes the entire Cenozoic history of the restraining bend. Present-day strain partitioning contrasts with published observations on finite deformation in Lebanon, demonstrating distributed shear and vertical-axis block rotations. Furthermore, the present-day proportions of strike-slip displacement and crustal shortening are inconsistent with the total strike-slip offset and the lack of a significantly thickened crust. This suggests that the present rate of crustal shortening has not persisted for the longer life of the transform. Hence, we suggest that the Lebanese restraining bend evolved in a polyphase manner, involving an earlier episode of wrench-faulting and block rotation, followed by a later period of strain partitioning.
\end{abstract}

Restraining bends, by definition, involve plate motions that are oblique to the associated transcurrent faults. An important question pertains to how oblique convergence is accommodated by crustal deformation. In an active tectonic setting, understanding the spatial distribution of crustal strain is important for assessing the earthquake hazard, as well as for understanding the tectonic evolution of the restraining bend.

The Dead Sea fault system (DSFS) is a prominent continental transform in the eastern Mediterranean region (Fig. 1). Along this transform system, a large (c.180-km-long) restraining bend along the Dead Sea fault system encompasses present-day Lebanon and SW Syria. Recent palaeoseismic (Gomez et al. 2001, 2003; Daeron et al. 2004 2005; Nemer \& Meghraoui 2006) and geodetic (e.g. Wdowinski et al. 2004; Reilinger et al. 2006) studies have shown that the strike-slip faults are unambiguously active within the Lebanese restraining bend, refuting suggestions to the contrary (e.g. Butler et al. 1997, 1998).

The 'Lebanese' restraining bend of the DSFS also can serve as an analogue for other large restraining bends along continental transform systems, including the Big Bend of the San Andreas Fault (e.g. Chaimov et al. 1990). In contrast to the Big Bend, the Lebanese restraining bend appears to be structurally less complicated, with fewer fault branches. Hence, it may be easier to assess the distribution and controls of crustal deformation, owing to the relative simplicity of the structure.

This paper synthesizes new results and recently published data to assemble a kinematic model for present-day tectonism in the Lebanese restraining 


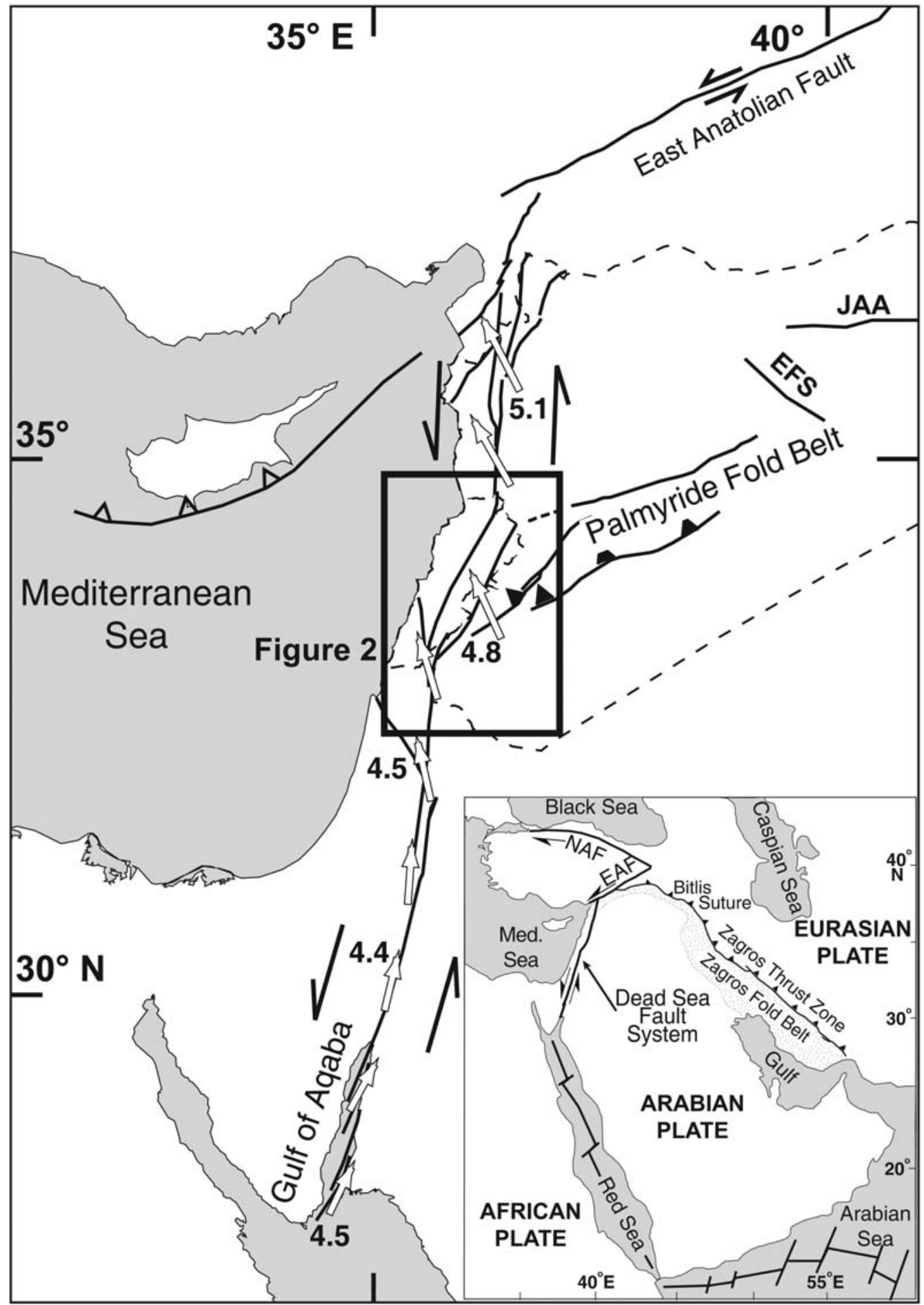

Fig. 1. Regional tectonic map of the Dead Sea fault system. Directions (white arrows) and rates (mm/a) of motion of the Arabian plate relative to the Sinai plate are based on the plate model of Reilinger et al. (2006). Abbreviations: JAA, Jebel Abdel Aziz; EFS, Euphrates fault system; NAF, North Anatolian fault; EAF, East Anatolian fault. Inset depicts the plate-tectonic setting of the Arabian-Eurasian collision. 
bend. Herein, we suggest that present-day transpression in the Lebanese restraining bend is described in terms of strain partitioning between the NE-SW strike-slip faults and zones of approximately NW-SE folding and thrust faulting. We will explore the implications of this strain partitioning for the long-term development of the restraining bend.

\section{Tectonic setting}

Within the tectonic framework of the Eastern Mediterranean, the north-south-striking, left-lateral DSFS spans $c .850 \mathrm{~km}$ from the Gulf of Aqaba to southern Turkey, accommodating differential convergence of the Arabian and Sinai plates relative to Eurasia (Fig. 1). The DSFS comprises three main sections (e.g. Quennell 1984; Garfunkel et al. 1981). These are a c.400-km-long southern section from the Gulf of Aqaba through the Dead Sea and Jordan River valleys; a c.250-km-long, north-south striking section in NW Syria and southern Turkey; and a c.180-km-long NE-SWstriking restraining bend through Lebanon and SW Syria that connects the two north-south sections. The restraining bend is the focus of this paper (Fig. 2).

A thorough overview of the history of research along the DSFS is provided by Beydoun (1999), and relevant aspects are summarized here. It is generally agreed that a first episode of tectonism occurred during the Mid- and Late Miocene, with c. $60 \mathrm{~km}$ of left-lateral displacement documented along the southern DSFS (e.g. Freund et al. 1970; Quennell 1984). The magnitude of slip along the northern DSFS during this earlier phase remains unknown, owing to a lack of piercing points of sufficient age. A second episode of motion began in the latest Miocene to Early Pliocene, corresponding with initiation of seafloor spreading in the northern part of the Red Sea (Hempton 1987), and continues through the present. The total displacements on the southern and northern sections during this episode are $45 \mathrm{~km}$ and $20-25 \mathrm{~km}$, respectively (Freund et al. 1970; Quennell 1984) - the difference in displacement may be accommodated by up to $20 \mathrm{~km}$ of shortening of the Palmyride fold belt (Chaimov et al. 1990).

The present-day relative motion of the Arabian and Sinai plates is well constrained by recent GPS studies (e.g. Wdowinski et al. 2004; Mahmoud et al. 2005; Reilinger et al. 2006). Owing to the position of the Euler pole describing relative plate motion $\left(32.8^{\circ} \mathrm{N} \pm 3.4^{\circ}, 28.4^{\circ} \mathrm{E} \pm 3.7^{\circ}\right.$; Reilinger et al. 2006), the convergent component of plate motion increases northward along the transform (Fig. 1). Consequently, within the Lebanese restraining bend, relative plate motion is oriented approximately $35^{\circ}$ to the NNE-SSW strike of the transform (Fig. 1). At the latitude of the restraining bend, the plate model of Reilinger et al. (2006) suggests $4.8 \pm 0.4 \mathrm{~mm} / \mathrm{a}$ of relative motion between the Arabian and Sinai plates. It should be noted that, owing to the constraints of the elastic block modelling used, the uncertainties on plate motion are considerably smaller than suggested by the uncertainties in the pole position (Reilinger et al. 2006). As shown in Figure 2, velocities of continuous GPS sites spanning the restraining bend clearly demonstrate left-lateral shear across the transform (Reilinger et al. 2006).

Physiographically, the Lebanese restraining bend consists of two distinct mountain ranges: the Mount Lebanon and Anti-Lebanon ranges, separated by the intermontane Bekaa Valley - a large synclinorium (Fig. 2). The highest topography in the restraining bend exceeds $3000 \mathrm{~m}$ in elevation. By modelling of gravity data, Khair et al. (1993) suggested that, despite the topography, the region possesses only a modest crustal root: the Moho is located c. $27 \mathrm{~km}$ beneath Mount Lebanon; $c .35 \mathrm{~km}$ beneath the Anti-Lebanon; and $c .33 \mathrm{~km}$ beneath the Arabian plate farther to the east in western Syria.

Mount Lebanon has the overall structure of a box-anticline (Fig. 3). Although initial folding of the anticlinorium was initiated in the Late Mesozoic/Early Cenozoic (Walley 1988), folding of Miocene and Quaternary strata in the northern Mount Lebanon region indicates that the Mount Lebanon range has experienced geologically recent folding. The Anti-Lebanon is a broad, open anticlinorium. If a probable offshore continuation of the deformation belt associated with Mount Lebanon (Daeron et al. 2004) is included, then Lebanese restraining bend is approximately $80-90 \mathrm{~km}$ wide. As demonstrated by Hancock \& Atiya (1979), the regional shortening is $10-15 \%$ $(9-16 \mathrm{~km})$, which is consistent with line-length restoration of Upper Cretaceous strata in the regional cross-section in Figure 3. Late Cenozoic deformation has also occurred within the adjacent region of the Arabian plate in the Palmyride fold belt (e.g. Chaimov et al. 1990), the Jebel Abdel Aziz of NE Syria (e.g. Brew et al. 1999), and the Euphrates fault system (e.g. Litak et al. 1997) (Fig. 1). Active internal deformation of the Arabian plate is also expressed by seismicity in the Palmyride fold belt (e.g. Sbeinati et al. 2005).

Along the flanks of the Anti-Lebanon, folded Neogene conglomerates indicate a pulse of Late Cenozoic folding (Ponikarov 1964). Remnants of a low-relief palaeosurface are also inferred within the high portions of the Mount Lebanon and Anti-Lebanon ranges (Gomez et al. 2006). This 

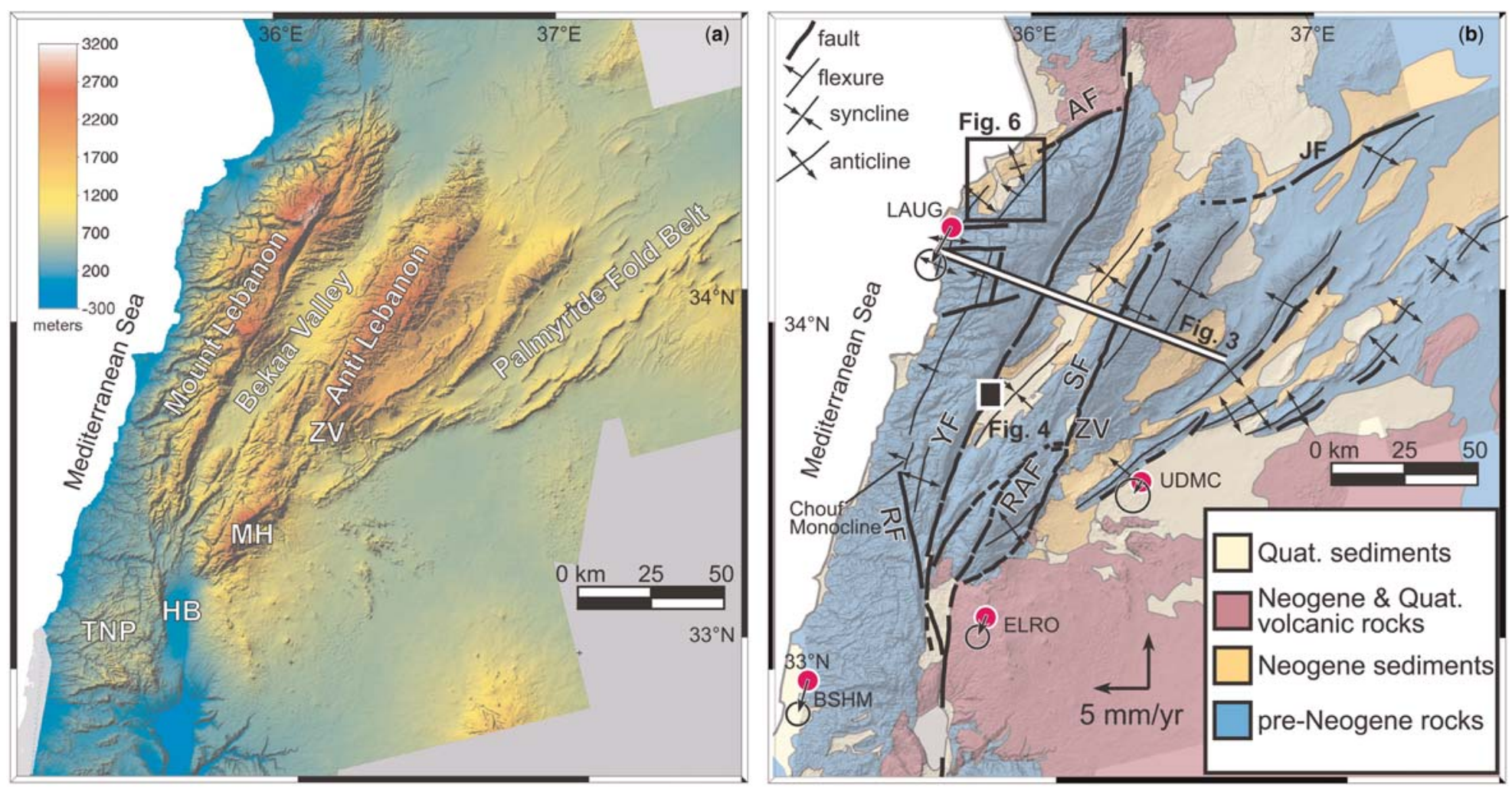

Fig. 2. (a) Map showing the topography of the Lebanese restraining bend from a 20-metre-pixel, InSAR-derived DEM (Gomez et al. 2006). (b) Map showing general geology (simplified from Dubertret 1955) and the structure of the restraining bend (simplified from Gomez et al. 2006). Arrows indicate velocities of continuous GPS sites (red circles) in an Arabia-fixed reference frame (Reilinger et al. 2006). GPS velocities depict the net left-lateral shear across the Dead Sea fault system in this area. White line = location of the cross-section in Figure 3. Abbreviations: YF, Yammouneh Fault, SF, Serghaya Fault; RF, Roum Fault, RAF, Rachaya Fault; JF, Jhar Fault; HB, Hula Basin; MH = Mount Hermon; TNP, Tyre-Nabatieh Plateau; and ZV, Zebadani Valley. 


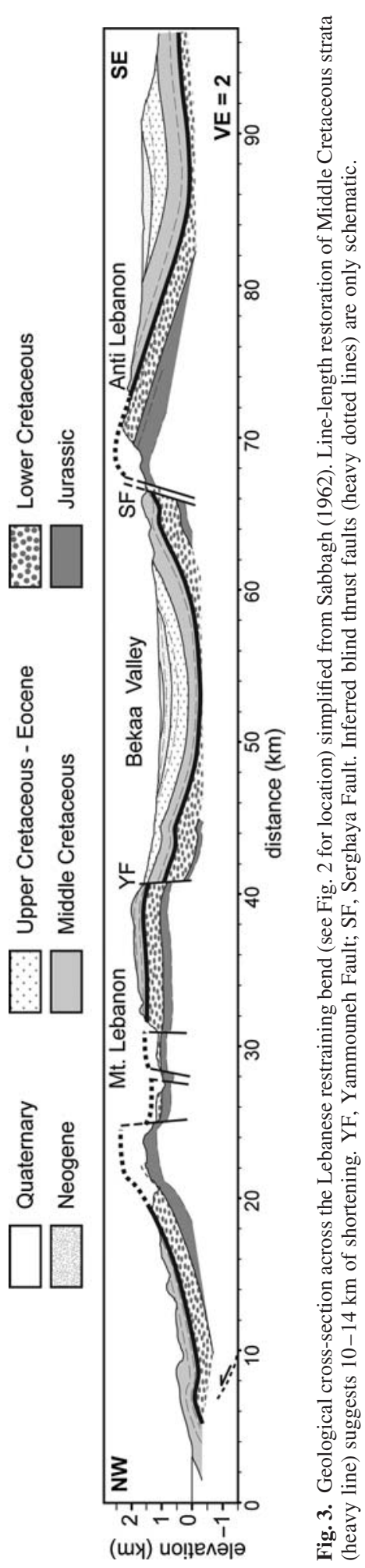

low-relief surface has been interpreted to be a Late Miocene erosional surface, owing to concordance with a regional unconformity of similar age in Syria. Many topographic escarpments parallel to the structural grain of the restraining bend and the Palmyride fold belt are erosional in nature - i.e. cuestaforms, rather than fault scarps (e.g. Dubertret 1955; Ponikarov 1964). Some tectonic maps of the restraining bend erroneously denote these as faults (e.g. Daeron et al. 2004) and imply more crustal shortening and thickening than has probably occurred. We emphasize the distinction here, because the crustal shortening is a key aspect of the restraining bend.

Within the restraining bend, the relatively simple north-south trace of the southern DSFS splays into several prominent structures as a 'braided' fault system (Walley 1988). These include the NE-SW-striking Yammouneh, Rachaya and Serghaya faults. Other structures include the north-south-striking Roum Fault and the ENE-WSW striking Akkar Fault - both of which bound the Mount Lebanon uplift. Some of these structures are probably inherited from prior tectonic episodes in the region. For example, the stratigraphic thickness changes across the Roum Fault (e.g. Dubertret 1955; Sabbagh 1962) suggest its activity during a Late Cretaceous rifting episode, and the Jhar Fault in the northern Palmyrides may correspond with a Precambrian suture (Best et al. 1990). On the other hand, Mesozoic stratigraphic thicknesses do not change across the Serghaya Fault (e.g. Fig. 3), which suggests that it is not a reactivated normal fault associated with the Late Cretaceous rifting.

Historical records of large, devastating earthquakes also attest to the activity and seismogenic potential of the central and northern DSFS, despite the scarcity of moderate and large events in instrumental records (e.g. Ambraseys \& Jackson 1998; Sbeinati et al. 2005). For example, it seems likely that a large earthquake in 1759 (Ambraseys \& Barazangi 1989) occurred along the Serhgaya branch of the DSFS (e.g. Gomez et al. 2003; Daeron et al. 2005). By summing estimated moments of large historical earthquakes over the past c.2000 years, Ambraseys (2006) estimated a seismic slip rate of $4-5 \mathrm{~mm} / \mathrm{a}$ for the entire DSFS, which is generally consistent with the total plate motion.

\section{Present-day strike-slip faulting}

To date, slip rates for several key strike-slip faults have been reported, including the Serghaya, Roum, and Yammouneh faults (Table 1). These slip rates, along with other structural details, are 
Table 1. Slip rates for major faults in the Lebanese restraining bend

\begin{tabular}{lcl}
\hline Fault & $\begin{array}{c}\text { Slip rate } \\
\text { (mm/a) }\end{array}$ & \multicolumn{1}{c}{ Reference } \\
\hline $\begin{array}{l}\text { Serghaya } \\
\text { Roum }\end{array}$ & $1.4 \pm 0.1$ & $\begin{array}{l}\text { Gomez et al. (2003) } \\
\text { Nemer \& } \\
\text { Meghraoui (2006) }\end{array}$ \\
$\begin{array}{l}\text { Yammouneh } \\
\text { Yammouneh }\end{array}$ & $5.1 \pm 1.3 \pm 1.1$ & $\begin{array}{l}\text { Daeron } \text { et al. (2004) } \\
\text { This study }\end{array}$ \\
\hline
\end{tabular}

synthesized in the following sections. We also provide further constraints on the slip rate of the Yammouneh strike-slip fault that have not been previously reported. As will be discussed later, these kinematic constraints may be sufficient to suggest that active transpression is partitioned between strike-slip deformation and perpendicular crustal shortening.

\section{Serghaya/Rachaya faults}

The Serghaya Fault splays from the main transform at the NE side of the Hula Basin (Fig. 2). The fault can be followed along the southern flank of Mount Hermon, and it bends NNE to trace obliquely across the Anti-Lebanon range (e.g. Dubertret 1955; Gomez et al. 2006). A reverse component of motion along the southern Serghaya Fault adjacent to Mount Hermon is consistent with the vertical juxtaposition of Jurassic strata on top of Cretaceous and Palaeocene strata (Dubertret 1955), as well as the SE vergence of the Mount Hermon anticlinorium (May 1989). The Serghaya Fault appears to terminate in the northern Anti-Lebanon: the distinct, linear geomorphic expression is distinct in the south, but becomes less pronounced to the north where the structure branches into several smaller, discontinuous splays. The termination of the Serghaya Fault suggests a possible linkage with the Jhar Fault as an oblique ramp or tear fault that bounds the Palmyride fold belt (e.g. Walley 1988; Gomez et al. 2003).

Walley (1998) suggested $20 \mathrm{~km}$ of total displacement along the Serghaya Fault, but the displaced markers are ambiguous. Other evidence of longterm offset can be gleaned from the large river valleys incised into the low-relief erosional surface of the Anti-Lebanon range. Consistent c. $6 \mathrm{~km}$ deflections of the largest river valleys and wind gaps suggest that a similar magnitude of left-lateral offset post-dates the erosional surface (Gomez et al. 2006).

A related structure is the Rachaya Fault, which also splays from the NE Hula Basin and traces along the northern flank of Mount Hermon. The linear trace of the Rachaya Fault is clear in the field, and faulted alluvial fans and a palaeoseismic investigation provide compelling evidence for active tectonism (Nemer 2005) - these field investigations find no evidence of reverse faulting along the Rachaya Fault as suggested by Daeron et al. (2005). At its northern termination, the Rachaya Fault splays as it bends toward the Serghaya Fault in the Zebadani Valley (e.g. Walley 1988; Gomez et al. 2006). The Rachaya Fault is not simply the southern part of the Serhgaya Fault, as suggested by Daeron et al. $(2004,2005)$ - there is a neotectonic fault south of Mount Hermon that connects with the Serghaya Fault. Rather, the geometry of the Serghaya and Rachaya faults, along with $c .60^{\circ}$ block rotations in the Mount Hermon region (Ron 1987) suggest that the Rachaya Fault and the Serghaya Fault may be structurally linked as a strikeslip 'duplex', following the model of Woodcock \& Fischer (1986).

A Holocene-averaged slip rate along the Serghaya Fault was determined in the palaeoseismic study of Gomez et al. (2003) in the Zebadani Valley. Based on a sequence of three displaced and abandoned channels exposed in the palaeoseismic excavation, a slip rate of $1.4 \pm 0.1 \mathrm{~mm} / \mathrm{a}$ was estimated. A small component of oblique slip on the Serghaya Fault was suggested by fault-plane striations as well as faulted landscape features (Gomez et al. 2001). However, the faults are subvertical at the surface, and it is unclear whether the dip-slip component $(c .0 .3 \mathrm{~mm} / \mathrm{a})$ reflects regional compression of the Anti-Lebanon range or local extension related to the releasing bend in the Serghaya Fault that corresponds with the Zebadani Valley. Published slip rates for the southern Serghaya Fault and the Rachaya Fault are presently lacking.

\section{Roum Fault}

The Roum Fault splays from the Yammouneh Fault in southern Lebanon, north of the Hula Basin. The NNW-SSE strike of the Roum Fault contrasts with the NNE-SSW strike of the other major faults in the restraining bend. The Roum Fault corresponds with a topographic lineament that bounds the topography of the southern Mount Lebanon range with the low relief of the Tyre-Nabatieh Plateau (Fig. 2). The fault lineament can be traced until approximately $33^{\circ} 40^{\prime} \mathrm{N}$ latitude. At the northern extent, the trace of the Roum Fault disappears as it bends northward and merges with the hinge of the Chouf monocline - the southern part of the larger Mount Lebanon monoclinorium (Griffiths et al. 2000; Khair 2001; Nemer \& Meghraoui 2006).

Meso- and micro-structures demonstrate primarily strike-slip displacement along the southern part 
of the Roum Fault, with increasing oblique slip (east side up) along the northern part of the fault (Griffiths et al. 2000; Nemer \& Meghraoui 2006). Griffiths et al. (2000) and Nemer \& Meghraoui (2006) documented a northward decrease in the amount of deflection of major drainages across the Roum Fault. This was inferred to represent a northward decrease in strike-slip offset along the fault.

Evidence of recent movement of the Roum Fault is provided by the misalignment of small streams, as well as sheared alluvium exposed in trench excavations (Nemer \& Meghraoui 2006). Along the southern part of the Roum Fault, Nemer \& Meghraoui (2006) estimated a slip rate of $0.8-$ $1.1 \mathrm{~mm} / \mathrm{a}$, based on the consistent offsets of small streams that incise a caliche horizon. Nemer \& Meghraoui observed consistent leftward, stream deflections of 9-11 metres, which were interpreted as left-lateral offsets. A maximum age of the incisions of $c .6400-8500 \mathrm{BC}$ was provided by radiocarbon dating of detrital charcoal and a bulk soil sample.

\section{Yammouneh Fault}

The Yammouneh Fault is the only through-going fault within the Lebanese restraining bend - i.e. it is the only structural link between the southern DSFS in the Jordan River Valley and the northern DSFS in NW Syria. The southern Yammouneh Fault generally bounds the west side of the southern Bekaa Valley, and the northern part of the fault passes through the northern Mount Lebanon Range adjacent to the crest of the range (Fig. 2). The fault's linear map trace suggests a subvertical fault in the upper crust (Fig. 3).

Walley suggested a total displacement of $47 \mathrm{~km}$ of left-lateral slip based on correlating Mesozoic geological structures between the Mount Lebanon and Anti-Lebanon ranges. Average, Quaternary slip rates of $c .5 \mathrm{~mm} / \mathrm{a}$ have been inferred from the displacement of the Litani River (Walley 1988; Westaway 2004). Displaced landforms, such as faulted alluvial fans and wind gaps, demonstrate that the Yammouneh Fault has experienced only strike-slip movements during the Late Quaternary (e.g. Daeron et al. 2004; Gomez et al. 2006), i.e. there is no evidence of recent or active dip-slip along the Yammouneh Fault.

Daeron et al. (2004) constrained a Late Pleistocene slip rate for the Yammouneh Fault of 3.8$6.4 \mathrm{~mm} / \mathrm{a}$, using faulted depositional fans. In the following section, we will provide additional cosmogenic age constraints on the more southerly of the two sites studied by Daeron et al. (2004). Despite some differences in the mapping and interpretation of the fault and adjacent landforms, our results complement those of Daeron et al. (2004). As discussed, our sampling strategy is different, and we also apply more recently published constraints on cosmogenic nuclide production rates. The integration of our results with those of Daeron et al. may improve the uncertainties on the timing of displacement.

\section{Additional constraints on the Yammouneh Fault}

Along the western side of the Bekaa Valley, a series of medium-sized alluvial fans are presently abandoned and incised by the modern channel drainage (e.g. Dubertret 1955). Among these, the Zalqa fan is located at approximately $33^{\circ} 50^{\prime}$. Unlike most other fans in the Bekaa Valley, the Zalqa fan is significant, owing to the fact that the Yammouneh Fault truncates the fan very near its apex (Fig. 4a).

In our study, detailed field mapping of the Zalqa fan was supported by high-resolution overhead imagery (2-metre pixel SPIN-2 satellite imagery and 1:20000 stereo aerial photographs). Field studies of the fan also involved mapping and surveying with kinematic GPS. As in the map made by Daeron et al. (2004), we also identified and mapped three alluvial surfaces (Fig. 4a): the oldest fan (Qf1), which comprises the largest volume of sediment; a smaller, but now incised intermediate fan (Qf2); and the active alluvial fan (Qf3). The Zalqa fan consists of sub-angular clasts of Upper Jurassic dolimitic limestone. The clastsupported sediments are poorly sorted, with clast sizes ranging from centimetre-sized gravel to boulders more than $2 \mathrm{~m}$ in diameter. Qf1 has a weakly developed soil with small pedogenic structures in the A horizon and very thin carbonate coatings on the clasts in the B horizon.

The present-day Zalqa drainage incises a 5-m canyon exposing sheared alluvium of Qf1 coinciding with the Yammouneh Fault (Fig. 4b) at approximately $1045 \mathrm{~m}$ altitude. At this location, the canyon also depicts an abrupt deflection of 5$8 \mathrm{~m}$, which may represent the true offset of the drainage.

The Yammouneh Fault truncates the fan approximately 150 metres from the apex - this permits a confident estimate of the total offset of the fan, rather than the diffuse depositional contacts along its edges. Topographic profiles radiating from the fan's apex down the Qf1 surface were measured using differential GPS, and these profiles depict the steep, but constant, slope of this fan. This suggests a single episode of aggradation has produced the Qf1 surface.

The geometry of the Zalqa fan is well preserved in the topography, and we constrained the location of the head of the fan using available 1:20 000 topographic maps, 2-m pixel Spin-2 satellite photos, and 

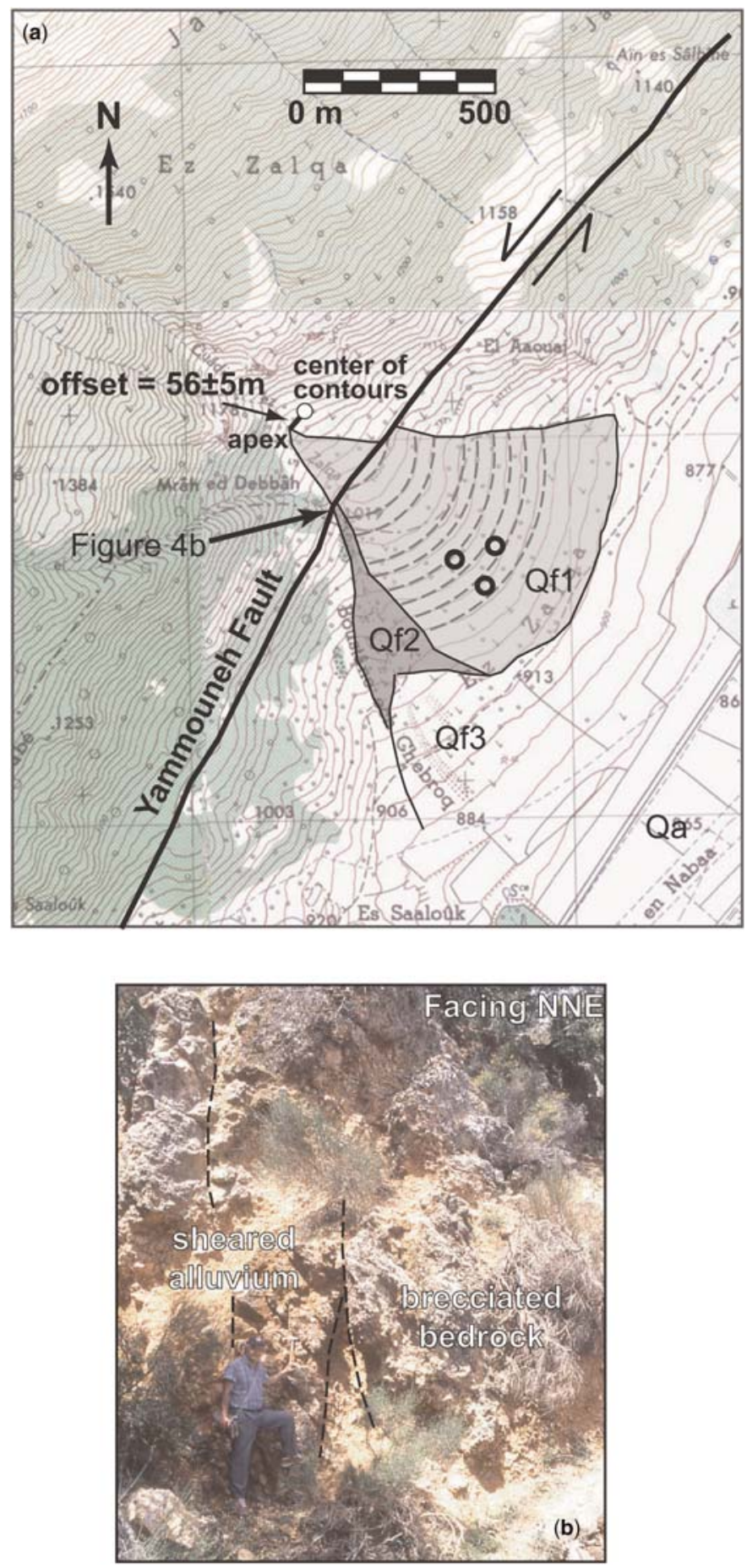

Fig. 4. (a) Map of the Zalqa Fan, based on field mapping and stereoscopic aerial photographs. Three fan surfaces are shown: Qf1 (oldest), Qf2 and Qf3 (youngest). Locations of samples for cosmogenic dating are indicated by the black circles. Dashed grey lines indicate the best-fit concentric circles for the topographic contours of the Qf1 surface. The 56-metre displacement of the Qf1 fan is indicated by the offset between the centre of these concentric circles and the present position of the fan's apex. (b) Photograph of shear alluvium and brecciated bedrock where the Yammouneh Fault intersects the Zalqa drainage (location shown in Fig. 4a). Dashed line denotes shear zones within the alluvium. 
field measurements (kinematic GPS). Offset of the fan was estimated from the displacement between the head of the fan and the fan apex, as defined by the morphology of the lower part of the fan. Alluvial fans typically have a conical geometry, owing to the abrupt deposition at the mouth of a confined mountain drainage (Bull 1977; Pinter et al. 1995) such geometry implies similar slopes radiating from the apex, rather than a single axis. In fact, the topographic contours of the Qf1 surface demonstrate a conical surface (concentric arcs in map view, see Fig. 4). The centre of these concentric arcs should correspond with the relative position of the fan's apex at the time of aggradation, and, following established methods (e.g. Pinter et al. 1995; Klinger et al. 2000), we believe that our approach correctly uses the properties of an alluvial fan to assess the offset of the Qf1 surface. Topographic contours were digitized and used to determine a best-fit set of concentric circles. The offset between the centre of these circles and the apex provides a measure of the displacement of $56 \pm 5$ metres.

As with the study of Daeron et al. (2004), we used in situ cosmogenic ${ }^{36} \mathrm{Cl}$ to date the age of the fan surface. 'Exposure' dating of landforms using cosmogenic nuclide concentrations has become a widely applicable technique (e.g. Gosse \& Phillips 2001). In situ cosmogenic nuclides result from interactions between cosmic rays and the constituent material in surficial rocks. Hence, concentrations of in situ cosmogenic nuclides are directly related to the duration that those particular rocks have been exposed at the surface. Production rates for a particular location can be estimated after considering environmental aspects such as elevation, latitude, topographic slope and shielding. Owing to the predominant carbonate clast lithology in the Zalqa fan, ${ }^{36} \mathrm{Cl}$ was used.

Whereas Daeron et al. (2004) dated numerous smaller cobbles from the fan surface, our efforts focused on large boulders of Jurassic limestone embedded within the fan surface. Samples from three distinct boulders embedded in the mid to upper half of the fan's surface were collected for cosmogenic ${ }^{36} \mathrm{Cl}$ dating (see Fig. 4 for locations). As these clasts are embedded in the top of the oldest fan, they provide a maximum age constraint on the timing of abandonment of the fan. All the boulders sampled showed minimal effects of burial or weathering - a 1-m test pit excavated adjacent to one of the boulders demonstrated a relatively intact A horizon, implying negligible soil erosion. The relatively short length of the drainage feeding the fan $(c .1 .5 \mathrm{~km})$ suggests that time in transit after erosion was probably minimal before the boulders were deposited in the fan surface. Following the procedure described by Gosse \& Phillips (2001), sample material was collected from the outer two centimetres of the boulders. Boulders showed little evidence of weathering (i.e. solution pits were negligible).

Chemical preparation of the samples was performed by the New Mexico Bureau of Mines, and the ${ }^{36} \mathrm{Cl}$ nuclide concentrations were measured using accelerator mass spectrometry (AMS) at Lawrence Livermore National Laboratory, California, USA. The isotopic concentrations are shown in Table 2. Numerical ages were modelled using the MS Excel-based CHLOE worksheet (Phillips \& Plummer 1996) and the production constants provided by Phillips et al. (2001). After corrections for environmental conditions, including those described above, the three samples yielded ages of 9.6-12.8 ka BP (Table 2). The production rates of Phillips et al. (2001) differ by c.25\% from those of Stone et al. (1998), which were applied by Daeron et al. (2005). Consequently, our ages appear younger: applying the production rates of Stone et al. yields ages of $12.5-16.6 \mathrm{ka} \mathrm{BP}$.

To improve the precision of the age estimate, we assume that all three boulders aggraded during the same episode - this seems reasonable, owing to the uniform slope of the fan. The total uncertainties include the uncertainty in the production rates and analytical results. Assuming that these uncertainties represent a Gaussian probability density function, the probabilities for each of the dates can be

Table 2. Results and production rates for ${ }^{36} \mathrm{Cl}$ dating

\begin{tabular}{lcccr}
\hline Sample & ${ }^{36} \mathrm{Cl} /{ }^{35} \mathrm{Cl}$ ratio & ${ }^{36} \mathrm{Cl} /{ }^{35} \mathrm{Cl}$ error & ${ }^{35} \mathrm{Cl} /{ }^{37} \mathrm{Cl}$ ratio & Age (years BP) \\
\hline MF-01-1 & $1.604 \times 10^{12}$ & $2.16 \times 10^{14}$ & 5.21 & $12800 \pm 1430$ \\
MF-01-2 & $1.381 \times 10^{12}$ & $3.29 \times 10^{14}$ & 5.56 & $11410 \pm 1390$ \\
MF-01-3 & $1.539 \times 10^{12}$ & $2.22 \times 10^{14}$ & 6.07 & $9810 \pm 1210$ \\
\hline Production & & & Mean age & $11200 \pm 790$ \\
${ }^{40}$ Ca spallation & $66.8 \pm 6.8$ & & & \\
${ }^{39}$ K spallation & $137 \pm 60$ & & & \\
Fast neutron & $626 \pm 105$ & & & \\
\hline
\end{tabular}

Production rates from Phillips et al. (2001) 
statistically combined to yield a final age of $11.20 \pm 0.81 \mathrm{ka}$ BP. This compares favourably with the youngest age group from the results of Daeron et al. (2005), especially after accounting for the different production rates used.

The timing of aggradation of the Zalqa Fan (and presumably the other fans of similar size along the western flank of the central Bekaa Valley) are consistent with a shift from cooler and drier conditions to warmer and more wetter conditions approximately $10-11 \mathrm{ka}$ ago in the eastern Mediterranean (this corresponds with the Younger Dryas event in Europe and North America). Rossignol-Strick (1993) interpreted the recent climate history of Lebanon and adjacent regions, based on palynological indicators. Near the end of the Late Pleistocene (approximately $11 \mathrm{ka}$ ) an abrupt change from arid to humid conditions was indicated by an abrupt change in vegetation. As described by Bull (2000), such a rapid shift in climate is conducive to alluvial fan aggradation.

These results constrain the maximum ages of abandonment of Qf1. Hence, these ages provided constraints on the minimum rate of slip along the Yammouneh Fault during the Holocene. With 51-61 metres of displacement, the slip rate is $3.9-6.1 \mathrm{~mm} / \mathrm{a}$.

\section{Kinematic model}

The slip rates for the Yammouneh and Serghaya faults (i.e. the two main NNE-SSW-striking fault systems) provide a basis for assessing how plate motion is accommodated within the restraining bend. Whereas Westaway $(1995,2004)$ applied a continuum model to finite strain in the Lebanese restraining bend, here we explore a relatively simple geometric model to explain the present-day (i.e. instantaneous) slip.

The recent plate model of Reilinger et al. (2006) predicts the movement of the Arabian plate relative to the Sinai plate at the Lebanese restraining bend to be $4.8 \pm 0.4 \mathrm{~mm} / \mathrm{a}$ oriented $\mathrm{N} 10^{\circ} \mathrm{W}$. When resolved with the $\mathrm{N} 25^{\circ} \mathrm{E}$ orientation of the master faults through this restraining bend, this plate motion can be broken down into $3.8 \mathrm{~mm} / \mathrm{a}$ of NNE-SSW strike-slip displacement on these faults and $3.1 \mathrm{~mm} / \mathrm{a}$ of perpendicular convergence. Within the uncertainties, this is consistent with the sum of the slip rates on the Serghaya/Rachaya and Yammouneh faults. In fact, the sum of the Late Quaternary strike-slip rates discussed herein $(5.2-7.5 \mathrm{~mm} / \mathrm{a})$ generally exceeds the total $4.0 \mathrm{~mm} / \mathrm{a}$ expected from plate motion, which may suggest that geological rates have been overestimated. Since these two faults sufficiently account for all expected strike-slip deformation, there is no need to involve additional distributed simple shear (i.e. wrenching) during the Late Quaternary. Recalling that the Yammouneh Fault demonstrates only strike-slip displacement, the only deformation that remains to be accommodated is the component of shortening perpendicular to the NNE-SSW strikeslip faults. Hence, it appears that oblique plate motion within the restraining bend is partitioned into strike-slip displacements and perpendicular convergence. This is consistent with the suggestion of Griffiths et al. (2000) that, during the Late Cenozoic, southern Mount Lebanon folds formed parallel to the NNE-SSW-striking Yammouneh Fault. This suggestion of strain partitioning was supported by the similar orientations of joint-bedding intersections and fold hinges - such a relationship would not be expected if rotation and wrenching were involved.

The newly available slip rates and revised plateboundary conditions allow the reassessment of our earlier geometric model for the Lebanese restraining bend (Gomez et al. 2003). The schematic model shown in Figure 5 also permits some shortening across the Palmyride fold belt, which seems reasonable owing to present-day seismicity in the Palmyride region. This model assumes a fixed fault geometry for Late Quaternary displacements. As in our previous model (Gomez et al. 2003), the Serghaya Fault acts as an oblique 'back-stop' to the Palmyride fold belt, and it links with the Jhar Fault in the northern Palmyride region. As illustrated in Figure 5, this geometric model does not involve a simple scalar addition of slip rates, because the Serghaya links directly to the internal deformation of the Arabian plate in the Palmyride fold belt. Considering the geometry of the Serghaya Fault relative to the shortening direction of the Palmyride fold belt, $1.4 \mathrm{~mm} / \mathrm{a}$ of left-lateral slip corresponds with $1.0 \mathrm{~mm} / \mathrm{a}$ of shortening across the entire Palmyride region. Hence, internal deformation of the Arabian plate in the Palmyrides may accommodate up to $20 \%$ of the total, relative plate motion at this latitude. The remaining $4.0 \mathrm{~mm} / \mathrm{a}$ of plate motion will be accommodated by the other structures in the restraining bend: $c .3 .2 \mathrm{~mm} / \mathrm{a}$ of NNE-SSE strike-slip along the Yammouneh Fault, and $2.2 \mathrm{~mm} / \mathrm{a}$ of orthogonal shortening.

Relatively complete strain partitioning has been documented in other large restraining bends along transform boundaries. For example, the Hispaniola restraining bend along the Caribbean-North American plate boundary appears to involve complete partitioning of slip between two strikeslip faults and an offshore thrust system to the north (Calais et al. 2002). Although structurally more complicated than the DSFS and the northern Caribbean plate boundary, strain partitioning is also observed along the Big Bend of the San Andreas Fault system (e.g. Becker et al. 2005), as 


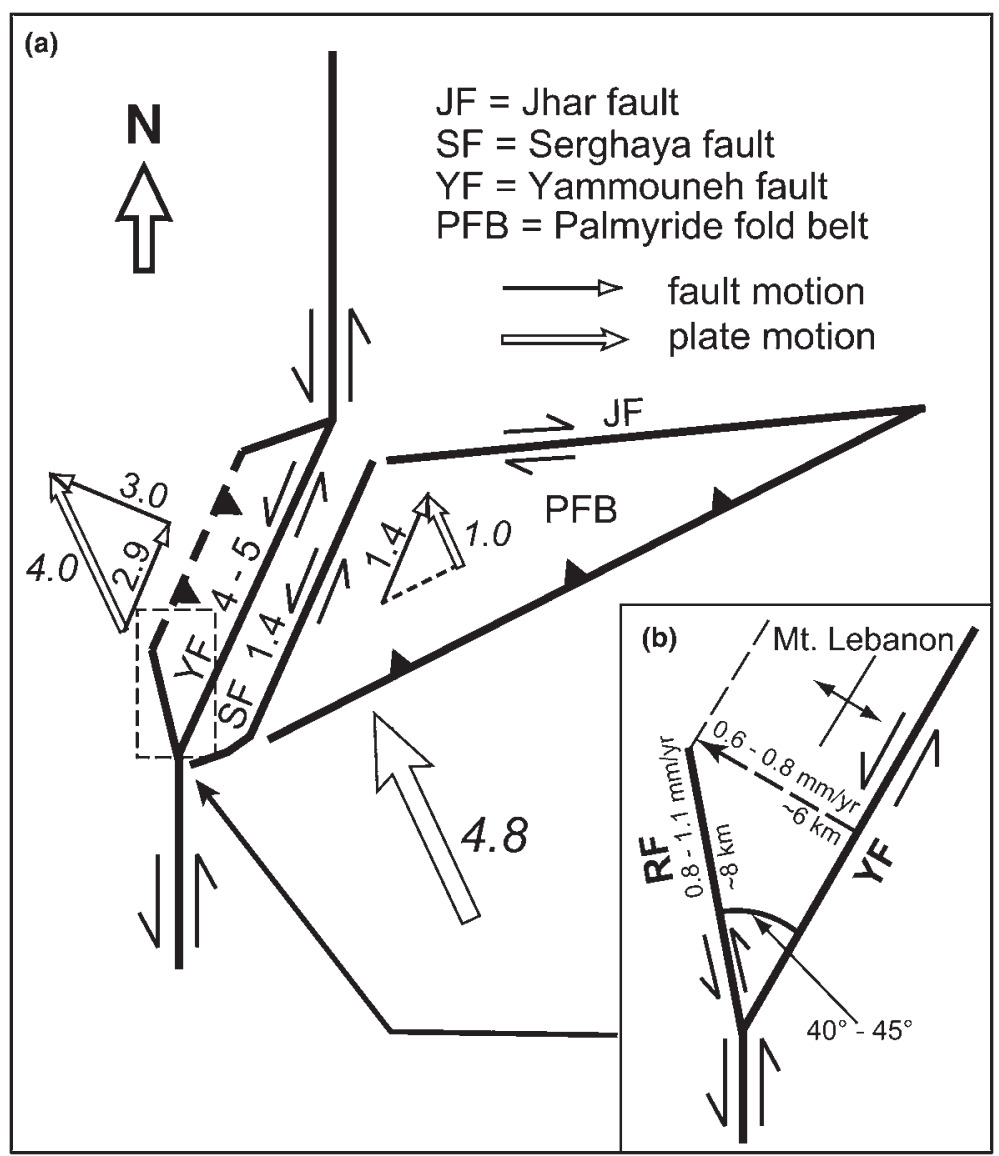

Fig. 5. (a) A possible geometric model for the Lebanese restraining bend (revised from Gomez et al. 2003).

Present-day plate motion is based on Reilinger et al. (2006). In this model, the Serghaya Fault serves as a bounding structure of the Palmyride fold belt, and contributes to internal deformation of the Arabian plate. After subtracting that shortening vector, the remaining plate motion is decomposed into strike-slip parallel to the Yammouneh Fault, and orthogonal shortening. Numbers represent rates in $\mathrm{mm} / \mathrm{a}$. Heavy dashed line indicates an inferred blind fault corresponding with the Coastal monocline of Lebanon. (b) Enlargement of the simplified geometry around the Roum Fault, indicating how the total slip and slip rate can be geometrically related to the total shortening and shortening rate. Total shortening of $6 \mathrm{~km}$ across the 30-km-wide region is consistent with the $10-15 \%$ total shortening reported by Hancock \& Atiya (1979).

well as along the central San Andreas Fault (e.g. Molnar 1992; Page et al. 1998), which is also oriented oblique to the relative plate motion. Both cases, as well as the Lebanese restraining bend, involve transform systems with significant total displacement and regionally distributed strain. In such cases, strain partitioning is likely, as it is a more stable kinematic configuration than oblique-slip faulting and wrenching (Molnar 1992).

\section{Contraction and crustal shortening}

Although the NE-SW strike-slip kinematics are becoming well constrained, constraints on
NE-SW contraction are still quite limited. However, we can explore possible constraints on rates and magnitudes of crustal shortening and thickening in the Mount Lebanon Range from two considerations: (1) the role of the Roum Fault as an accommodation structure, and (2) rates of coastal uplift.

\section{The Roum Fault and Mount Lebanon shortening}

Compared with the Yammouneh and Serghaya faults, the Roum Fault is unusual, owing to its $\mathrm{N} 10-15 \mathrm{~W}$ strike and the displacement gradient 
along strike. Strain compatibility requires that the inferred northward decrease in displacement along the Roum Fault be accommodated by folding of the adjacent Mount Lebanon Range. Hence, the Roum Fault serves as an 'oblique ramp' structure bounding the Mount Lebanon folds (Griffiths et al. 2000).

With this concept in mind, the displacement and slip rate along the Roum Fault can be used to predict the expected WNW-ESE shortening in the southern Mount Lebanon. The Mount Lebanon folds trend $c . \mathrm{N} 30^{\circ} \mathrm{E}$, implying shortening $\mathrm{N} 60^{\circ} \mathrm{W}$. This shortening direction makes a $40-45^{\circ}$ angle with the N10-15W strike of the Roum. Based on the geometry of the Roum fault and the WNWESE shortening, the $c .8 \mathrm{~km}$ of total displacement (Griffiths et al. 2000; Nemer \& Meghraoui 2006) suggests that the southern part of Mount Lebanon has been shortened by $c .6 \mathrm{~km}$ (Fig. $5 \mathrm{~b}$ ). Considering the $c .30 \mathrm{~km}$ width of the southern part of Mount Lebanon (between the Yammouneh Fault and the Chouf monocline), this corresponds with $17 \%$ horizontal shortening - slightly larger than (but not necessarily inconsistent with) the $10-15 \%$ bulk shortening reported by Hancock \& Atiya (1979). This similarity between expected and predicted total shortening supports the plausibility of the geometric model in Figure 5.

A similar geometric exercise can be applied to the slip rates. In this case, the $0.8-1.1 \mathrm{~mm} / \mathrm{a}$ Holocene slip rate would correspond with a shortening rate of $0.6-0.8 \mathrm{~mm} / \mathrm{a}$. This shortening rate is significantly less than the $2.2 \mathrm{~mm} / \mathrm{a}$ predicted from the geometric model in Figure 5. This suggests that WNW-ENE horizontal shortening is presently being accommodated in other parts of the Lebanese restraining bend, such as offshore Lebanon and in the Anti-Lebanon Range.

\section{Coastal uplift}

Coastal uplift is another expected manifestation of crustal shortening and thickening within the restraining bend. Late Cenozoic shortening and uplift is particularly well expressed along the coast in northern Lebanon near Tripoli (Fig. 6). South of Tripoli, the Jaouz anticline involves folded Miocene-Pliocene strata (Fig. 7). In the core of the Zagharta syncline to the SW, Lower Quaternary deposits also appear slightly back-tilted, suggesting recent folding. North of Tripoli, Late Cenozoic shortening is also expressed in the deformation of Miocene and Pliocene strata in the Turbol anticline (Fig. 6).

Compelling evidence for recent coastal uplift is suggested by notched shorelines along the Lebanese coast (Fig. 8). The relative sea-level changes represented by notched coastlines may involve both true eustatic variations (which will correlate with global climate variations) and tectonic uplift of the coast. Notched shorelines in northern Lebanon are higher than those along the Syrian coast
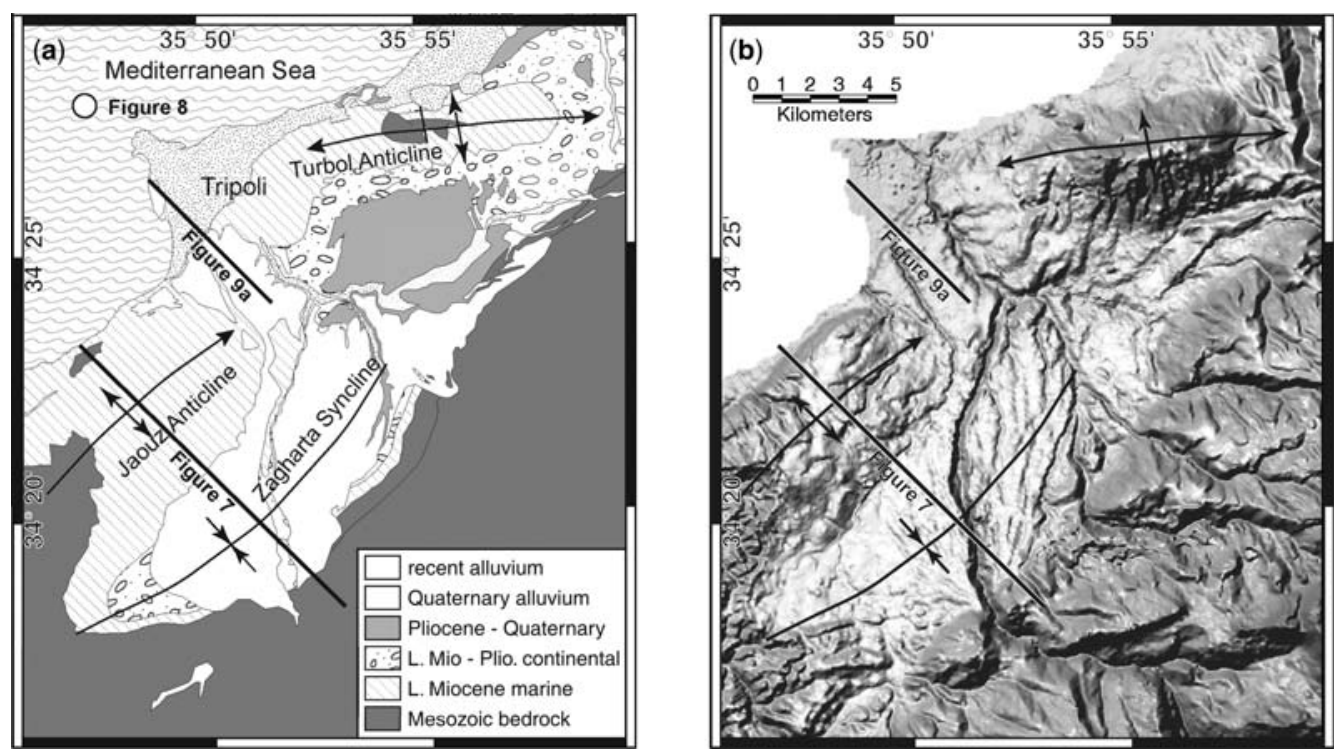

Fig. 6. (a) Map showing simplified geology (from Dubertret 1955), and (b) map of topography in the region of Tripoli (based on Gomez et al. 2006). Locations of the profiles in Figures 7 \& 9a are shown, as well as the location of the photograph in Figure 8. 


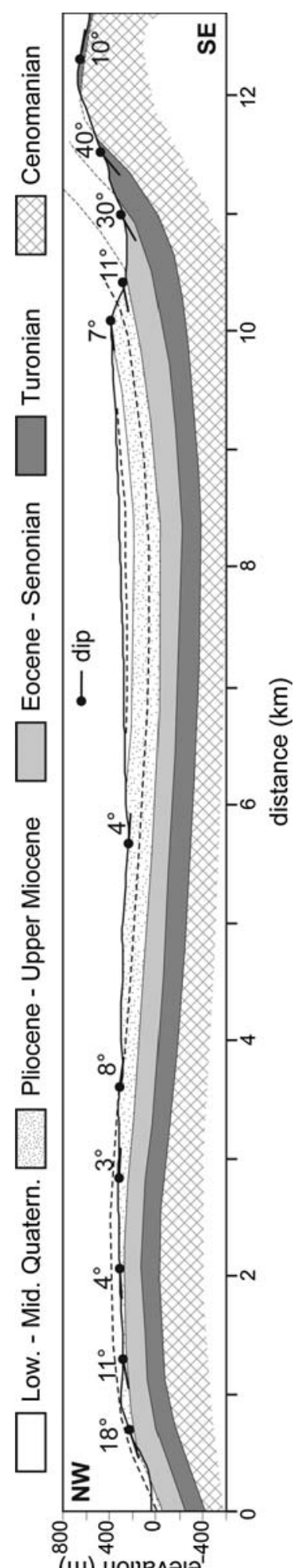

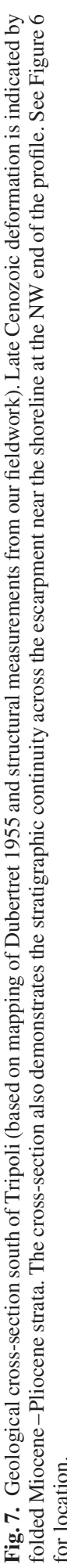

(Pirazolli et al. 1996), which is consistent with the expected increase in crustal shortening within the Lebanese restraining bend. Evidence of Mid- to Late Quaternary uplift is provided by flights of coastal terraces along the Lebanese coast, particularly near Tripoli (e.g. Sanlaville 1974). Along the north Lebanese coast, marine terraces are eroded on to Mesozoic and Tertiary strata (e.g. Sanlaville 1977), and exposures in road cuttings and stream valleys demonstrate these are typically overlain by a thin $(2-3 \mathrm{~m})$ veneer of Late Quaternary sedimentary cover. The escarpments corresponding with the risers of these coastal terraces are topographically prominent, involving cliff heights in excess of $50 \mathrm{~m}$ (Sanlaville 1977). We emphasize here that these escarpments are erosional in nature, as indicated by the continuity of lithological units across the escarpments (e.g. the cross-section in Fig. 7). Furthermore, our field investigation of these scarps identified no evidence for faulting, such as brecciated bedrock or a gouge zone associated with these escarpments.

Radiocarbon dating of vermetid gastropod shells suggests that notched shorelines near Tripoli with heights of $c .1 \mathrm{~m}$ and $c .2 \mathrm{~m}$ represent two abrupt uplift events that occurred between $c .770 \mathrm{BC}$ and c.550 AD (Sanlaville 1974, 1977; Pirazolli et al. 1996 and references cited therein). The most recent may correspond with the large, historically documented earthquake that occurred in Lebanon in $551 \mathrm{AD}$ (Darawcheh et al. 2000). Ages of higher terraces and shoreline features are less well constrained. On the basis of Middle Palaeolithic artifacts, Bowen \& Jux (1987) suggested that a well-developed terrace at 7-15 metres above sealevel corresponds with the Eem Interglacial (c.125 ka BP).

By taking the altitudinal positions of the terraces and their sea-level history into consideration, it is possible to quantify the rates of uplift of the Lebanese coast during the Middle and Late Quaternary (e.g. Bloom et al. 1974). Marine terraces are planar surfaces that generally slope seaward up to $3-4^{\circ}$. The 'shoreline angle' where the wave-cut platform meets the steep sea-cliff and is preserved at the top of the terrace indicates sea-level at the high stand. The elevations of these shoreline angles were interpolated from topographic profiles extracted from 1:20000 topographic maps and spot-checked for several locations in the field. In total, six distinct terrace surfaces were identified in eight profiles north and south of Tripoli - an example is shown in Figure 9a, and mean values are provided in Table 3. We believe that coastal uplift in the northern Mount Lebanon may be representative of the entire Mount Lebanon range, as the most extensive, upper terraces correlate regionally in Lebanon (e.g. Bowen \& Jux 1987). 


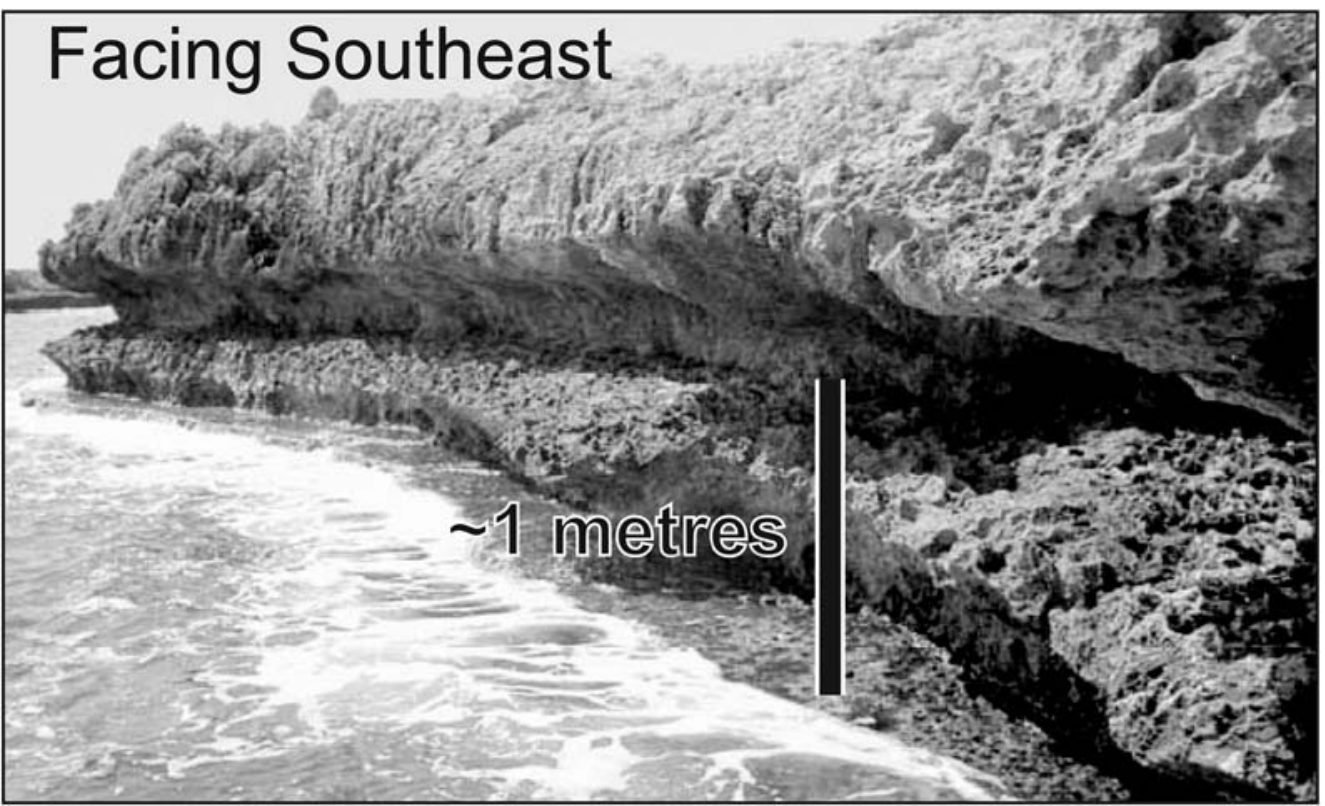

Fig. 8. Photograph from Ramkine Island, offshore of Tripoli, showing a notched shoreline indicating the recent emergence of the coastline. See Figure 6 for location.
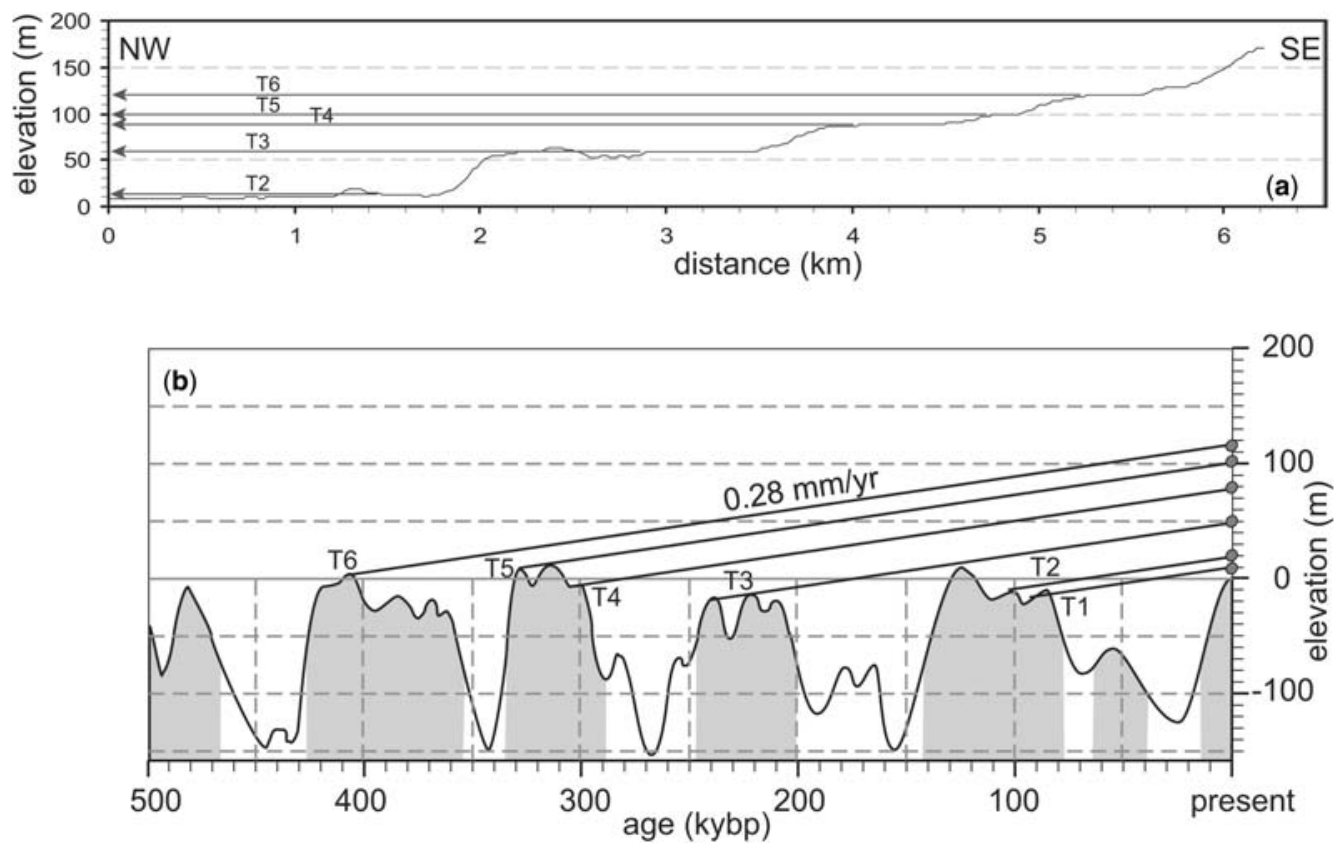

Fig. 9. (a) Example topographic profile and shoreline angles in the Tripoli region (see Fig. 6 for location). Six distinct shoreline angles have been identified from eight profiles, and these values are summarized in Table 3 .

(b) Correlation of terrace altitude with sea-level high stands during the past $500 \mathrm{ka}$ (Shackleton \& Opdyke 1973; Pinter \& Gardner 1989) assuming a constant rate of uplift. An uplift rate of $0.28 \mathrm{~mm} / \mathrm{a}$ best fits the data. 
Table 3. Mean elevation of coastal terraces in northern Lebanon

\begin{tabular}{lc}
\hline Terrace & Mean elevation $(\mathrm{m})$ \\
\hline T1 & 10 \\
T2 & 22 \\
T3 & 53 \\
T4 & 81 \\
T5 & 104 \\
T6 & 119 \\
\hline
\end{tabular}

Shoreline angles corresponding with coastal terraces were measured from eight topographic profiles in northern Lebanon.

Following the method outlined by Pinter (1996), we infer rates of coastal long-term uplift by correlating the relative vertical spacing of terrace heights with sea-level variations during the past c.500 ka (Shackleton \& Opdyke 1973). Marine terraces typically form during sea-level high stands. For this analysis, we assumed that the rate of uplift has been constant during the Late Quaternary. Using these constraints, linear regression resulted in an uplift rate of $0.28 \mathrm{~mm} / \mathrm{a}$ that best fit the heights of the terraces - the results are graphically depicted in Figure 9b. This rate of uplift is considerably slower than the $0.75-1 \mathrm{~mm} / \mathrm{a}$ that may be inferred from the notched shorelines discussed by Pirazolli et al. (1996). One possible explanation may be that uplift rates can be overestimated over short time periods if earthquakes demonstrate temporal clustering behaviour.

We assume that the uplift deduced from terraces near Tripoli is representative of uplift in the Mount Lebanon region and that this uplift is directly related to crustal thickening and NW-SE shortening. This uplift rate is a minimum estimate on the rate of crustal thickening if there is no isostatic compensation. If the growth in topography is isostatically compensated, thickening is faster. Assuming Airy isostasy, the change in thickening $(\Delta t)$ and uplift rate are related as:

$$
\left.\Delta t=\Delta h \times\left\{1+E \rho_{\mathrm{c}} /\left(\rho_{\mathrm{m}}-\rho_{\mathrm{c}}\right)\right]\right\},
$$

where $\rho_{m}$ is the density of the mantle and $\rho_{c}$ is the bulk crustal density. Using typical values for these densities $\rho_{\mathrm{m}}=3.3 \mathrm{~g} / \mathrm{cm}^{3} ; \rho_{\mathrm{c}}=2.7 \mathrm{~g} / \mathrm{cm}^{3}$ yields $\Delta t=5.5 \Delta h$. Hence, $0.28 \mathrm{~mm} / \mathrm{a}$ of coastal uplift corresponds with a maximum crustal thickening of $1.5 \mathrm{~mm} / \mathrm{a}$.

Although there is considerable uncertainty in relating crustal thickening to horizontal shortening, a maximum horizontal shortening rate can be inferred by assuming that all shortening is accommodated by crustal thickening. A first-order estimate will assume a block of crust of uniform thickness. The Mount Lebanon part of the restraining bend is approximately $40-50 \mathrm{~km}$ wide and underlain by a 27-30 -km-thick crust (Khair et al. 1993). For these dimensions, thickening of $1.5 \mathrm{~mm} / \mathrm{a}$ will correspond with shortening of 2.1-2.7 mm/a, which is comparable, but slightly less than the $2.6-3.1 \mathrm{~mm} / \mathrm{a}$ suggested by relative plate motions and the kinematic model in Figure 5. To accommodate the full shortening within the Mount Lebanon Range may require either greater uplift rate (which is not observed) or a wider zone of deformation than the $40 \mathrm{~km}$ between the Yammouneh Fault and the limit of the offshore fold belt. As with the discussion of the Roum fault and the southern Mount Lebanon, this suggests that some shortening may be accommodated within the Anti-Lebanon and Palmyride fold belts.

\section{Implications for long-term development of the LRB}

Since the present-day slip rates along the main NNE-SSW strike-slip faults account for all expected strike-slip deformation within the restraining bend, there is no need for distributed simple shear away from the faults. Hence, present-day regional kinematics seem well explained in terms of nearly complete regional strain partitioning, which does not involve tectonic wrenching (e.g. Tikoff \& Teyssier 1994; Jones \& Tanner 1995). On the other hand, this kinematic model does not seem applicable to the long-term, Cenozoic tectonic development of the Lebanese restraining bend: vertical-axis rotations, finite strain expressions of distributed shear, are suggested from palaeomagnetic studies. On Mount Lebanon, counterclockwise rotations of $30^{\circ}$ are inferred from Cretaceous rocks (Van Dongen et al. 1967; Gregor et al. 1974). Similarly, rotations of at least $30^{\circ}$ and more have been reported in the southern Anti-Lebanon region around Mount Hermon (Ron 1987). The exact timing of these post-Cretaceous rotations is uncertain: some have attributed the rotations to the present (i.e. neotectonic) activity (e.g. Ron 1987; Westaway 1995), whereas others have suggested that these correspond with earlier deformation (e.g. Walley 1998; Westaway 2004). Although the counterclockwise sense of rotation is consistent with left-lateral shear along the Dead Sea fault system, the Late Quaternary strain partitioning suggests that rotation and wrenching occurred earlier.

To reconcile the present-day kinematics with the finite deformation, we suggest herein that the 

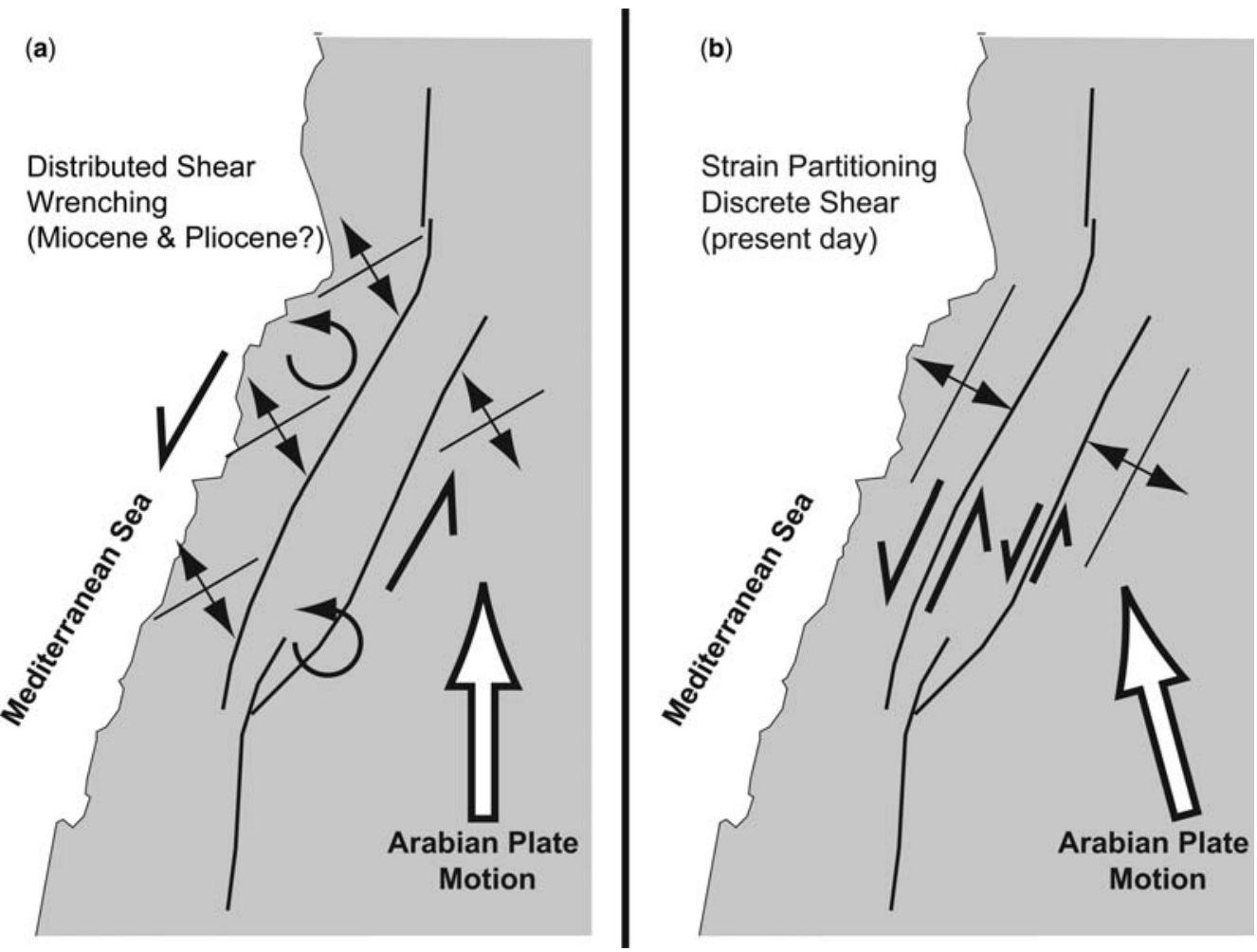

Fig. 10. Proposed two-stage evolution of the Lebanese restraining bend. An earlier phase involves wrenching and rotation (a). A later phase involves strain partitioning (b). It also seems likely that plate motions associated with these two episodes have changed over time.

Lebanese restraining bend has experienced a polyphase tectonic evolution (Fig. 10):

- An earlier deformation, involving wrenching, distributed shear, block rotation and less crustal shortening (relative plate motion less oblique to the restraining bend) (Fig. 10a).

- A later (and active) phase of tectonism involving strain partitioning and increased convergence (increased obliquity of plate motion relative to the restraining bend) (Fig. 10b).

Wrenching and distributed shear would evolve to regional strain partitioning as wrench-related folds (which originally form oblique to the strikeslip faults) rotate counterclockwise to become oriented subparallel to the strike-slip faults. The result is the present-day configuration of strain partitioning. This proposed kinematic history is similar to that suggested by Miller (1998) for the present-day slip partitioning along the central San Andreas Fault.

Furthermore, the present proportion of WNWESE crustal shortening and strike-slip is inconsistent with total estimates of shortening and strike-slip. Today, the obliquity of plate motion relative to the restraining bend resolves fault slip into $4.0 \mathrm{~mm} / \mathrm{a}$ strike-slip and $2.8 \mathrm{~mm} / \mathrm{a}$ orthogonal shortening. Assuming that these proportions of strike-slip and shortening have been maintained for the course of the Cenozoic, the total $105 \mathrm{~km}$ of strike-slip displacement along the southern DSFS would resolve into $80 \mathrm{~km}$ and $67 \mathrm{~km}$ of strikeslip and shortening, respectively. Similarly, considering only the $45 \mathrm{~km}$ from the second phase of DSFS movement implies $34 \mathrm{~km}$ of strike-slip displacement and $29 \mathrm{~km}$ of shortening within the restraining bend. Even for the latter second case, the shortening predicted is considerably greater than the $9-16 \mathrm{~km}$ of shortening implied by Hancock \& Atiya (1979). This suggests either (1) that the present proportions of strike-slip and shortening are characteristic only of the latest Cenozoic, or (2) that some shortening has been accommodated by lateral extrusions (e.g. Jones et al. 1997; Gomez et al. 1998). Although extensional structures west of the Roum Fault are consistent with some component of lateral extrusion (Griffiths et al. 2000), changing plate-boundary conditions are also likely. 
Garfunkel (1981) suggested that the Euler pole describing Arabian-Sinai plate motions has evolved through the Late Cenozoic with a progressively eastward position (i.e. closer to the transform). The implication of such a change in plate motion would be increasing obliquity of plate motion resolved along the transform (Fig. 10a). This increased component of convergence along the central and northern DSFS served as the basis for suggesting that the restraining bend, as well as the northern DSFS, was no longer active, owing to the geometrically incompatible orientation of those parts of the transform (Butler et al. 1998). Although recent geological and geodetic studies have strongly refuted the suggested inactivity of the central and northern DSFS, the suggestion of an evolving plate motion has merit. Within the context of the two-stage model in Figure 10, we suggest that increased compression within the restraining bend (resulting from increased convergence) may have favoured reactivation of the preexisting, rotated folds and contractional faults, rather than the development of new structures.

\section{Conclusions}

The Late Quaternary kinematics of the Lebanese restraining bend seem adequately reconciled with present-day plate boundary conditions by a model of strain partitioning. This model has implications for the understanding of the regional earthquake hazard, in that multiple, seismogenic structures are active - this has been demonstrated by recent palaeoseismic investigations along key faults (e.g. Gomez et al. 2003; Daeron et al. 2005; Nemer \& Meghraoui 2006). Additionally, the discrete structures that accommodate horizontal shortening may include seismogenic, blind faults, expressed at the surface only as folds such as the Jaouz and Turbol anticlines. These structures warrant further investigation, particularly owing to their proximity to the city of Tripoli.

The present-day strain partitioning model is inconsistent with the long-term (Late Cenozoic) finite deformation in the Lebanese restraining bend. Reconciling the present configuration with these long-term constraints seems to require a change in crustal kinematics during the Late Cenozoic.

This Lebanese restraining bend may serve as an example of the complex tectonic history associated with the development of restraining bends in general. Present-day strain partitioning is observed in large restraining bends along other transformfault systems (e.g. Hispaniola and the Big Bend of the San Andreas Fault). These restraining bends are long-lived features along fault systems that have hundreds of kilometres of total displacement. Hence, strain partitioning may be characteristic of mature fault systems that have experienced significant regional strain.

We thank F. Phillips and T. Thomas for assistance with the analysis of the ${ }^{36} \mathrm{Cl}$ results. Fieldwork associated with this study benefited from significant logistical support provided by the Lebanese National Center for Remote Sensing. C. Burchfiel and L. Seeber provided helpful reviews of this manuscript. We also thank P. Mann and D. Cunningham for feedback and helpful suggestions on this paper. We also acknowledge the assistance of S. Lepley. Research included in this paper was partially supported by US National Science Foundation grants EAR-0340670 and EAR-0439021. This research was also partially supported by University of Missouri Research Board grant URB04-102.

\section{References}

Ambraseys, N. N. 2006. Comparison of frequency of occurrence of earthquakes with slip rates from longterm seismicity data: the cases of the Gulf of Corinth, Sea of Marmara and Dead Sea Fault Zone. Geophysical Journal International, 165, 516-526.

Ambraseys, N. N. \& BARAZANGI, M. 1989. The 1759 earthquake in the Bekaa Valley: implications for earthquake hazard assessment in the Eastern Mediterranean region. Journal of Geophysical Research, 94, 4007-4013.

Ambraseys, N. N. \& JACKSON, J. A. 1998. Faulting associated with historical and recent earthquakes in the Eastern Mediterranean region. Geophysical Journal International, 133, 390-406.

Becker, T. W., Hardebeck, J. L. \& Anderson, G. 2005. Constraints on fault slip rates of the Southern California plate boundary from GPS velocity and stress inversions. Geophysical Journal International, 160, 634-650.

Best, J. A., Barazangi, M., Al-SAad, D., Gebran, A. \& SAWAF, T. 1990. Bouguer gravity trends and crustal structure of the Palmyride Mountain belt and surrounding northern Arabian platform in Syria. Geology, 18, 1235-1239.

Beydoun, Z. R. 1999. Evolution and development of the Levant (Dead Sea Rift) Transform System: a historical-chronological review of a structural controversy. In: MACNIOCAILl, C. \& RYAN, P. D. (eds) Continental Tectonics. Geological Society, London, Special Publications, 164, 239-255.

Bloom, A. L., Broecker, W. S., Chappell, J. M. A., Matthews, R. K. \& Mesolella, K. J. 1974. Quaternary sea level fluctuations on a tectonic coast: new ${ }^{230} \mathrm{Th} /{ }^{234} \mathrm{U}$ dates from the Huon Peninsula, New Guinea. Quaternary Research, 4, 185-205.

Bowen, R. \& Jux, U., 1987. The drama of climate change. In: Afro-Arabian Geology: A kinematic view. Chapman and Hall, New York, 212-232.

Brew, G., Litak, R., Barazangi, M. \& SAWAF, T. 1999. Tectonic evolution of northeast Syria: regional implications and hydrocarbon prospects. GeoArabia, 4, 289-318. 
Bull, W. B. 1977. The alluvial fan environment. Progress in Physical Geography, 1, 222-270.

BulL, W. B. 2000. Correlation of fluvial aggradation events to times of global climate change. In: Noller, J. S. \& Sowers, J. M. (eds) Quaternary Geochronology: Methods and Applications. American Geophysical Union. AGU Reference Shelf, 14, 456-464.

Butler, R. W. H., Spencer, S. \& Griffiths, H. M. 1997. Transcurrent fault activity on the Dead Sea Transform in Lebanon and its implications for plate tectonics and seismic hazard. Journal of the Geological Society, London, 154, 757-760.

Butler, R. W. H., Spencer, S. \& Griffiths, H. M. 1998. The structural response to evolving plate kinematics during transpression: evolution of the Lebanese restraining bend of the Dead Sea Transform. In: Holdsworth, R. E., Strahan, R. A. \& Dewey, J. F. (eds), Continental Transpressional and Transtensional Tectonics. Geological Society, London, Special Publications, 135, 81-106.

Calais, E., Mazabraud, Y., Mercier de Lepinay, B., Mann, P., Mattioli, G. \& Jansma, P. 2002. Strain partitioning and fault slip rates in the northeastern Caribbean from GPS measurements. Geophysical Research Letters, 29, doi:10.1029/2002GL015397.

Chaimov, T. A., Barazangi, M., Al-SaAd, D., SawaF, T. \& Gebran, A. 1990. Crustal shortening in the Palmyride fold belt, Syria, and implications for movement along the Dead Sea fault system. Tectonics, 9, 1369-1386.

Daeron, M., Benedetti, L., TApponnier, P., Sursock, A. \& Finkel, R. 2004. Constraints on the post $\sim 25$-Ka slip rate of the Yammouneh fault (Lebanon) using in situ cosmogenic ${ }^{36} \mathrm{Cl}$ dating of offset limestone-clast fans. Earth and Planetary Science Letters, 227, 105-119.

Daeron, M., Klinger, Y., TAPPOnnier, P., Elias, A., JACQUes, E. \& Sursock, A. 2005. Sources of the large A.D. 1202 and 1759 Near East earthquakes. Geology, 33, 529-532.

Darawcheh, R., Sbeinati, M. R., Margottini, C. \& PaOlini, S. 2000. The 9 July 551 AD Beirut earthquake, Eastern Mediterranean region. Journal of Earthquake Engineering, 4, 403-414.

Dubertret, L. 1955. Carte Geologique du Liban. Lebanese Ministry of Public Works, Beirut.

Freund, R., GARfunkel, Z., ZaK, I., GoldberG, M., WeIssbrod, T. \& DERIN, B. 1970. The shear along the Dead Sea rift. Philosophical Transactions of the Royal Society of London, Series A, 267, 107-130.

GARFUnKEL, Z. 1981. Internal structure of the Dead Sea leaky transform (rift) in relation to plate kinematics. Tectonophysics, 80, 81-108.

Garfunkel, Z., ZaK, I. \& Freund, R. 1981. Active faulting in the Dead Sea Rift. Tectonophysics, 80, $1-26$.

Gomez, F., Khawlie, M., Tabet, C., Darkal, A. N., Khair, K. \& Barazangi, M. 2006. Late Cenozoic uplift along the northern Dead Sea transform in Lebanon and Syria. Earth and Planetary Science Letters, 241, 913-931.

Gomez, F., Allmendinger, R., Barazangi, M., ER-RAJi, A. \& DAhMANI, M. 1998. Crustal shortening and vertical strain partitioning in the Middle Atlas Mountains of Morocco. Tectonics, 17, 520-533.

Gomez, F., Meghraoui, M. ET AL. 2001. Coseismic displacements along the Serghaya fault: an active branch of the Dead Sea fault system in Syria and Lebanon. Journal of the Geological Society, London, $\mathbf{1 5 8}$ 405-408.

Gomez, F., Meghraoui, M. ET AL. 2003. Holocene faulting and earthquake recurrence along the Serghaya branch of the Dead Sea fault system in Syria and Lebanon. Geophysical Journal International, 153, $658-674$.

Gosse, J. C. \& Phillips, F. M. 2001. Terrestrial in situ cosmogenic nuclides: theory and application. Quaternary Science Reviews, 20, 1475-1560.

Gregor, C. B., Mertzman, S., Narin, A. E. M. \& NegendanK, J. 1974. Palaeomagnetism and the Alpine tectonics of Eurasia 5: the palaeomagnetism of some Mesozoic and Cenozoic volcanic rocks from the Lebanon. Tectonophysics, 21, 375-395.

Griffiths, H. M., Clark, R. A., Thorp, K. M. \& SPENCER, S. 2000. Strain accommodation at the lateral margin of an active transpressive zone: geological and seismological evidence from the Lebanese restraining bend. Journal of the Geological Society, London, 157, 289-302.

HANCOCK, P. L. \& ATIYA, M. S. 1979. Tectonic significance of mesofracture systems associated with the Lebanese segment of the Dead Sea transform fault. Journal of Structural Geology, 1, 143-153.

Hempton, M. R. 1987. Constraints on Arabian plate motion and extensional history of the Red Sea. Tectonics, 6, 687-705.

JONES, R. R. \& TANNER, W. G. 1995. Strain partitioning in transpression zones. Journal of Structural Geology, 17, 793-802.

Jones, R. R., Holdsworth, R. E. \& BAILEy, W. 1997. Lateral extrusion in transpression zones: the importance of boundary conditions. Journal of Structural Geology, 19, 1201-1217.

KHAIR, K. 2001. Geomorphology and seismicity of the Roum fault as one of the active branches of the Dead Sea fault system in Lebanon. Journal of Geophysical Research, 106, 4233-4245.

Khair, K., Khawlie, M., Haddad, F., Barazangi, M., Seber, D. \& Chaimov, T. 1993. Bouguer gravity and crustal structure of the Dead Sea transform fault and adjacent mountain belts in Lebanon. Geology, 21, 739-742.

Klinger, Y., Avouac, J. P., Abou Karaki, N., Dorbath, L., Bourles, L. \& Reys, J. 2000. Slip rate on the Dead Sea transform fault in the northern Araba Valley (Jordan). Geophysical Journal International, 142, 755-768.

Litak, R. K., Barazangi, M., Beauchamp, W., Seber, D., Brew, G., SAWAF, T. \& Al-Youssef, W. 1997. Mesozoic-Cenozoic evolution of the intraplate Euphrates fault system, Syria: implication for regional tectonics. Journal of the Geological Society, London, 154, 653-666.

Mahmoud, S., Reilinger, R., McClusky, S., Vernant, P. \& Tealeb, A. 2005. GPS evidence for northward motion of the Sinai block: implications 
for E. Mediterranean tectonics. Earth and Planetary Science Letters, 238, 217-227.

MAY, P. R. 1989. Low-angle Overthrusting of Mount Hermon: A Working Hypothesis. Annual MeetingIsrael Geological Society, 1989, 102 pp.

MilleR, D. D. 1998. Distributed shear, rotation, and partitioned strain along the San Andreas fault, central California. Geology, 26, 867-870.

Molnar, P. 1992. Brace-Goetze strength profiles, the partitioning of strike-slip and thrust faulting at zones of oblique convergence, and the stress-heat flow paradox of the San Andreas Fault. In: Evans, B. \& WonG, T.-F. (eds) Fault Mechanics and Transport Properties of Rocks. Academic Press, New York, 435-459.

NEMER, T. 2005. Sismotectonique et comportement sismique du relais transpressif de la faille du Levant : rôles et effets des branches de failles sur l'aléa sismique au Liban. Université Louis Pasteur, Strasburg, PhD dissertation, 208 pp.

Nemer, T. \& Meghraoui, M. 2006. Evidence of coseismic ruptures along the Roum fault (Lebanon): a possible source for the AD 1837 earthquake. Journal of Structural Geology, 28, 1483-1495.

Page, B. M., Thompson, G. A. \& Coleman, R. G. 1998. Late Cenozoic tectonics of the central and southern Coast Ranges of California. Geological Society of America Bulletin, 110, 846-876.

Phillips, F. M. \& Plummer, M. A. 1996. CHLOE: a program for interpreting in-situ cosmogenic nuclide data for surface exposure dating and erosion studies. Radiocarbon, 38, p. 98.

Phillips, F. M., Stone, W. B. \& FABryka-Martin, J. T. 2001. An improved approach to calculating lowenergy cosmic-ray neutron fluxes near the land/atmosphere interface. Chemical Geology, 175, 689-701.

Pinter, N. \& GARDNer, T. W. 1989. Construction of a polynomial model of sea level: estimating palaeo-sea levels continuously through time. Geology, 17, 295-298.

PInter, N. 1996. Exercises in Active Tectonics. PrenticeHall, New York, 166 pp.

Pinter, N. \& Keller, E. A. 1995. Geomorphic analysis of neotectonic deformation, northern Owens Valley, California. Geologische Rundschau, 84, 200-212.

Pirazolli, P. A., Laborel, J. \& Stiros, S. C. 1996. Earthquake clustering in the Eastern Mediterranean during historical times. Journal of Geophysical Research, 101, 6083-6097.

Ponikarov, V. P. 1964. Geological Map of Syria. Ministry of Industry, Damascus, Syria.

Quennell, A. M. 1984. The Western Arabia rift system. In: Dixon, J. E. \& Robertson, A. H. F. (eds) The Geological Evolution of the Eastern Mediterranean. Geological Society of London, Special Publications, 17, 775-788.

REILINGER, R., MCClusky, S. ET AL. 2006. GPS constraints on continental deformation in the AfricaArabia-Eurasia continental collision zone and implications for dynamics of plate interactions. Journal of Geophysical Research, 111, doi:10.1029/ 2005JB004051.
RoN, H. 1987. Deformation along the Yammuneh, the restraining bend of the Dead Sea transform: palaeomagnetic data and kinematic implications. Tectonics, 6, 653-666.

Rossignol-STRICK, M. 1993. Late Quaternary climate in the Eastern Mediterranean region. Palaeorient, 19, $135-152$.

Sabbagh, G. 1962. Geological Cross Section Across Northern Lebanon. American University of Beirut Archive, Beirut.

SANLAVILLE, P. 1974. Le role de la mer dans les aplanissesments cotiers du Liban. Revue de Geographie de Lyon, 49, 295-310.

Sanlaville, P. 1977. Etude Géomorphologique de la Région Littorale du Liban. Lebanese University, Beirut, $859 \mathrm{pp}$.

Sbeinati, M. R., Darawcheh, R. \& Mouty, M. 2005. The historical earthquakes of Syria: an analysis of large and moderate earthquakes from 1365 B.C. to 1900 A.D. Annals of Geophysics, 48, 347-435.

ShaCKLETON, N. J. \& OpDYKe, N. D. 1973. Oxygen iosotope and palaeomagnetic stratigraphy of equatorial Pacific core V28-238: oxygen isotope temperatures and ice volume on a $10^{5}$ and $10^{6}$ year time scale. Quaternary Research, 3, 39-55.

Stone, J. O. H., Evans, J. M., Fifield, L. K., Allan, G. L. \& Cresswell, R. G. 1998. Cosmogenic chlorine-36 production in calcite by muons. Geochimica et Cosmochimica Acta, 63, 433-454.

TIKofF, B. \& TEYssier, C. 1994. Strain modeling of displacement-field partitioning in transpressional orogens. Journal of Structural Geology, $\mathbf{1 6}$, $1575-1588$.

VAn Dongen, P. G., VAn Der Voo, R. \& RaVen, T. 1967. Palaeomagnetism and the Alpine tectonics of Eurasia 3: palaeomagnetic research in the central Lebanon mountains and in the Tartous area (Syria). Tectonophysics, 4, 35-53.

WALLEY, C. D. 1988. A braided strike-slip model for the northern continuation of the Dead Sea Fault and its implications for Levantine tectonics. Tectonophysics, 145, 63-72.

Walley, C. D. 1998. Some outstanding issues in the geology of Lebanon and their importance in the tectonic evolution of the Levantine region. Tectonophysics, 298, 37-62.

WDOWINSKI, S., Bock, Y. ET AL. 2004. GPS measurements of current crustal movements along the Dead Sea Fault. Journal of Geophysical Research, 109, doi: 10.1029/2003JB002640, 2004.

Westaway, R. 1995. Deformation around stepovers in strike-slip fault zones. Journal of Structural Geology, 17, 831-846.

Westaway, R. 2004. Kinematic consistency between the Dead Sea Fault Zone and the Neogene and Quaternary left-lateral faulting in SE Turkey. Tectonophysics, 391, 203-237.

Woodcock, N. H. \& FISCHER, M. 1986. Strikeslip duplexes. Journal of Structural Geology, 8, $725-735$. 